\title{
Children and Rural-Urban Inequality of Health Among Elderly in China: "Convergence Phenomenon" of the Number of Children and "Action Mechanism" of the Quality of Children
}

\author{
Zhenhua Zheng \\ University of Shanghai for Science and Technology \\ Yusu Chu \\ University of Shanghai for Science and Technology \\ Yang Liu \\ Yangtze Normal University \\ Yingchen Lu \\ University of Shanghai for Science and Technology \\ Wanting Liu \\ University of Shanghai for Science and Technology \\ Ning Sun \\ University of Shanghai for Science and Technology \\ Hong Chen ( $\nabla$ ch_jhxy@sina.com ) \\ Sichuan University
}

\section{Research Article}

Keywords: health inequality, number of children, Quality of children, Health in old age

Posted Date: February 23rd, 2022

DOI: https://doi.org/10.21203/rs.3.rs-1301907/v1

License: (c) This work is licensed under a Creative Commons Attribution 4.0 International License. Read Full License 


\section{Abstract}

Background: There is a widespread health inequality between urban and rural elderly people in China. China's unique social culture, policy environment and family relations determine the importance of children to the health of the elderly. However, the existing research on the health inequality of urban and rural elderly in China was generally reflected in the discussion of the urban-rural dual structure and the socioeconomic status of the elderly, but ignoring the important role of children in the health of the elderly in China and that in the health inequality of urban and rural elderly in China.

Methods: The data we used come from the 2014 China Longitudinal Aging Social Survey (CLASS). In total, 9745 valid samples were obtained. The statistical method used in this

study was the structural equation modeling method(SEM).

Results: the degree of health inequality between urban and rural elderly decreases with the increase of the number of children. Children's quality, especially their economic status, played an important role in the health of the elderly, and was even significantly greater than the impact of their own socio-economic status.

Conclusion: With the increase of the number of children, the health gap between urban and rural elderly in China showed a "convergence phenomenon", and the urban-rural health inequality of the elderly and the urban-rural gap of children's economic conditions changed in the same direction. The economic conditions of children were not only an important factor affecting the health of the elderly, but also one of the important reasons for the convergence of the urban-rural health gap of the elderly with the increase of the number of children.

\section{Background}

Health equality is often used as an important dimension in assessing social development [1], however, health differences objectively exist among different social groups. The health status of the population with higher socio-economic status is usually better than that with lower socio-economic status, which is known as health inequality $[2,3]$. Since the publish of Black Report [4], health inequality has been an important issue in the international acedemic community [5, 6, 7]. Our research focuses on the issue of urban-rural health inequality among the elderly in China, which not only affects the life quality of the elderly, but also restricts the healthy growth of social equity and social harmony in China $[8,9]$.

Previous studies on the health inequality between the elderly of the urban and rural area in China mainly include two aspects: phenotypic characteristics and internal mechanisms. The research on phenotypic characteristics mainly confirmed that the health level of the rural elderly is significantly lower than that of the urban elderly $[10,11,12]$; while the studies on internal mechanism focuses on a discussion of the dual structure of China's urban and rural areas. (The gaps between the urban and rural areas, in terms of economic development level, social insurance system, medical security level and social and economic status, have led to the health inequality between urban and rural elderly[13, 14].)

In fact, the mechanism underlying health inequality among the elderly in China's urban and rural areas is quite special: the social unit of China is family rather than individual [15], and the family is an inter-generational interdependent "community". The elderly tend to have significantly lower levels of income, education and health knowledge than their adult children, who become the backbone of the family. The health problems of the elderly are more affected by the family, especially the children. At the same time, China's social old-age security system is not yet fully developed, nor does it fully cover the urban and rural areas[16], which objectively further aggravates the dependence of the elderly on their families, especially their children. Therefore, in this social context, a study of the socioeconomic status of individuals without considering the effects of family, especially children, would result in a loss of important determinants of health in elderly $[17,18]$

Previous studies mainly focused on the disccusion on the effects of the quality and quantity of children on health of elderly. The concept of children's quality was first put forward by Greenstein (1976), who pointed out that socioeconomic status is 
the main content of children's quality. The significant effect of children's quality on the disability and mortality in elderly has been widely confirmed[17, 19, 20, 21], which even outweighs that of the elderly' own socioeconomic status (Torssander, 2014; Yahirun, 2016)[20, 22]. Meanwhile, some scholars point out that the impact of the quality of children on the health of elderly is more pronounced in countries where more children live with their parents and where welfare systems are inadequate (Torssander, 2013)[23]. However, there is no consensus in terms of the relationship between the quantity of children and the health of elderly. Some scholars agree that the more children, the higher the level of well-being of elderly (Buber \& Engelhardt, 2008; Angeles, 2010; Shiyong and Jia, 2016)[15, 24, 25], but some argue that the number of children has an adverse effect on the health of elderly $[26,27]$. There are also some scholars who indicated that number of children is not the only factor that influences the support of parents, which needs some external factors to; while the quality of children is more often the more important factor to guarantee the effectiveness of children (Xia Chuanling and Ma Fengli, 1995)[28].

So, the positive effect of the quality of children on the health status of the elderly has been agreed by many scholars, but the effect of the number of children on the health status of the elderly has not been agreed. The reason is related to the different logical relationship between the number and quality of children to the health of elderly. For Chinese families, the socioeconomic status of adult children plays a greater role in the extended family than that of the elder family members. Therefore, there is a logical constistency between the effect of children's quality and that of the elderly's own socioeconomic status on the health of elderly $[30,31]$. However, the logical relationship is different in terms of the number of children. The number of children is not directly related to the family economic status of the elderly, or even to the living environment and lifestyle of the elderly, it directly determines only the family structure of the elderly, intergenerational patterns and the number of potential caregivers.

The logical relationship between the number of children, the quality of children and the health of the elderly is different, and is not suitable for direct horizontal comparison. Families with different number of children have different structure, and the intergenerational relationship and interaction between the elderly and their children are also different, and thus the intrinsic mechanism of the quality of children affecting the health of the elderly may also be different. In addition, the differences between China's urban and rural fertility policies have led to widespread differences in the fertility rates of the elderly between urban and rural areas. If all the elderly in urban and rural areas are directly compared, the difference of fertility structure between urban and rural areas may lead to the deviation of the conclusion of health inequality between urban and rural areas of the elderly, and also may lose the important information of health inequality between urban and rural areas of the elderly with different number of children.

Our study grouped the families in the urban and rural areas of China based on the number of their children, compared the urban and rural differences in the health status of elderly people in different groups and how they were affected by the quality of their children. It will not only help to fully reveal the factors affecting the health of the elderly, but also help to explore the underlying mechanism of health inequality between urban and rural areas. we developed a conceptual model of the effect of children's quality on the health of elderly (Fig. 1). The main purposes of our study are as follows: 1 . To comprehensively reveal the characteristics of health inequality between the urban and rural elderly in China through comparison of the health gap between the urban and rural elderly with different number of children; 2 . To compare the differential effects of the quality of children on the health of the elderly with different numbers of children in urban and rural areas; 3 . To compare the differential effects of the socioeconomic status of the elderly and the quality of their children on the health of the elderly. The conclusion of this study highlights the effect of Children's quality on the health inequality between urban and rural elderly. Our research expanded the research perspective of the health inequality of the elderly in theory, and enriched the research contents about the health inequality of the elderly in Chinese urban and rural area and its underlying mechanism. In practice, our conclusions will provide reference for the formulation of public policy on aging and help to promote the development of active aging.

\section{Methods}


Study population. The data used in this study is from the 2014 China Longitudinal Aging Social Survey (CLASS). It is a national and continuous large-scale social survey project conducted by the China Survey and Data Center, Renmin University of China, Among the Chinese aged 60 and above, the social and economic background of the elderly and the situation of their children are collected regularly and systematically. The purpose of CLASS is to find the issues facing by the elderly during aging and to provide data base for the study and solve of the problem of aging in China. Because CLASS obtained very detailed informations on the socio-economic status of elderly with different numbers of children and their children in different ranks, it is particularly appropriate to study the relationship between intergenerational socio-economic status and the health of elderly.

The survey adopted the multi-layer and multi-stage probability sampling method, covering 29 provinces, autonomous regions or municipalities, which include 134 counties, districts and 462 villages, with a sample size of 11,511. This research mainly concerns about the aspects of CLASS such as the education, income, health status of the elderly and the education and economic conditions of their children. After excluding the 1227 elderly whose annual income data was null and those have missing values of other variables, 9745 of the 11,201 elderly who have given birth were finally selected for analysis. Among them, 1192, 1588 and 2534 valid samples in urban areas and 305, 1055 and 3071 in rural areas have one child, two children, and three or more children respectively.

\section{Measurement}

Health of the elderly.The self-evaluation of the elderly on their physical and relative health status is a more comprehensive reflection of their health condition, which includes not only the combination of past and present health condition, but also the future health, resistance to disease and the extent to concern about the health (Yip et al., 2007; Read et al., 2016)[32, 33]. It has also been pointed out that subjective health assessment is more important than actual medical measurements (Maddox et al., 1973; Ocampo, 2010)[34, 35], therefore, the self-rated health and relative health were used to measure the health status of the elderly. The self-rated health was based on comprehensive evaluation of their own health status by the interviewees, and the relative health of the interviewees was scored from 1 to 5 relative to the health status of other people of the same age. The higher the score, the healthier the elderly.

The quality of children and the socioeconomic status of the elderly. The quality of children is generally expressed by their socio-economic status (Shi Zhilei, 2015)[36]. Economic level and educational level are used as the measurement variables in this study.

On a scale of 1 to 5 , the economic conditions of children in the CLASS survey were "very difficult (poverty)", "relatively difficult", "basically adequate", "relatively rich" and "very rich", respectively, representing the degree of economic condition of children from poverty to affluence. The educational attainment scores of the elderly and their children ranged from low to high: 1. Can't read, 2. Primary School (private school or literacy class), 3. Middle School, 4. High School or Technical Secondary School, 5. Junior college or above.

On one hand, all the variables in the model are in order of Grade 5, and the same measurement standard is more helpful to compare the variables in the model with different number of children, on the other hand, income data is often obtained with a fuzzy feature, and income and health is not a simple linear relationship, research income for each additional 1 unit, a few additional units of health, is not very significant, only by comparing the health of different income groups can policies be made and implemented (Fang Fuqian, Lv Wenhui, 2009)[37]. In this paper, the scores of the income level of the elderly are divided according to the quantiles of $20,40,60$ and 80 of the total sample income. The final scores from low to high are as follows: Below 2000 yuan (less than 20 deciles) is the low income level, and the score is 1; The median income level is 7200 yuan (between 20-40th quartile) with a score of 2; the median income level is 20000 yuan (between 40-60th quartile) with a score of 3; and the median income level is 32164 yuan (between 60-80th quartile) with a score of 4; more than 32164 yuan (more than 80th percentile) is the high income level, the score is 5. 
Control variable.The most commonly used age in related studies were selected as control variables in this paper. In addition, in examining the intergenerational relationship of Chinese families and the health status of the elderly, the living arrangement of children and the family size of the daily life of the elderly are also factors that need to be considered. It reflects the organization of family life and determines the interaction of family members at the structural level, especially the interaction between the elderly and their children (Chen Junming, Chen Qi, 2016)[38]. Therefore, this study takes whether to live with their children as a control variable.

In order to avoid the possibility of regional differences in the number of different children of the elderly, we chose the residential location as the control variable. This variable is an ordered class variable, and the scores from 1 to 5 are "the central city of the city/county", "the edge city of the city/county", "the urban-rural fringe of the city/county", and "town outside city/county", "rural areas".

In addition, to distinguish differences in provincial economic development level, we chose provincial GDP per capita as a control variable.

Statistical analyses.Descriptive statistical analysis combined with structural equation model (SEM) has more advantages in dealing with the overall problem of measurement variables and group comparison (Kuklys, 2005)[39]. In this study, the measurement models of health status, children's education level and children's economic conditions of the elderly with one, two and more children were analyzed by multi-factor confirmatory analysis. The composition reliability of all measurement models was greater than 0.6 , the average extraction of variance (AVE) was greater than standard (0.5), the factor loading of the observed variables was greater than 0.6 , and the reliability coefficient (SMC) was greater than 0.36 , All measurement models (CFA) had good reliability and validity, which were suitable for SEM analysis. The final fitness indexes (X2/DF $<5$, FGI > 0.90, AGFI P > 0.90, CFI P > 0.9, RMSER < 0.08) met the criteria, which shown that the model had good fitness.

\section{Results}

The statistical characteristics of each variable in different samples are shown in Table 1. Among them, the health level of urban elderly was slightly higher than that of rural elderly and the health level of elderly declined with the increase in the number of children. The level of education for elderly was generally low, averaging below junior high school levels. The educational level and income level of the elderly showed the same characteristics among different groups, that was, the urban aboriginal was higher than the rural, and more children were lower than less children. Children's economic conditions were also better in urban areas than in rural areas, but the gap between urban and rural areas was much smaller than the gap between the income and education levels of the elderly and the education level of children between urban and rural areas. The total sample mean of children's education level was around 3.3, only junior high school and less than high school level, and the education level of rural areas was generally below middle school and significantly lower than urban areas. The children's education level gradually decreased with the increase of the number of children. The economic situation of children between urban and rural areas was also better than that in rural areas, but the gap between urban and rural areas was far less than that of children's education level between urban and rural areas. The mean age of the sample was close to 70 years old, and there was no difference between the mean age of the urban and rural samples, and the mean age increased gradually with the increase of the number of children. The gender of the sample was close to the median value of 1.5 (male $=1$, female $=2$ ) in the total sample, urban and rural areas, and in the sample of different number of children clusters, indicating a more balanced sample of males and females. The average number of people living together was more than 3 , more rural than urban. 
Table 1

The descriptive statistics of the variables

\begin{tabular}{|c|c|c|c|c|c|c|c|c|}
\hline \multirow[t]{2}{*}{ Variable } & & & \multicolumn{6}{|c|}{ Mean Scores } \\
\hline & & & $\begin{array}{l}\text { All } \\
\text { samples }\end{array}$ & $\begin{array}{l}\text { Samples } \\
\text { in rural } \\
\text { areas }\end{array}$ & $\begin{array}{l}\text { Samples in } \\
\text { urban } \\
\text { areas }\end{array}$ & $\begin{array}{l}\text { One } \\
\text { child }\end{array}$ & $\begin{array}{l}\text { Two } \\
\text { children }\end{array}$ & $\begin{array}{l}\text { Three } \\
\text { or more } \\
\text { children }\end{array}$ \\
\hline \multirow{2}{*}{$\begin{array}{l}\text { The health status of } \\
\text { the elderly }\end{array}$} & \multicolumn{2}{|c|}{ The self-rated health } & 3.21 & 3.03 & 3.36 & 3.47 & 3.38 & 3.05 \\
\hline & \multicolumn{2}{|l|}{ Elative health } & 3.11 & 3.01 & 3.20 & 3.46 & 3.13 & 3.04 \\
\hline \multirow[t]{2}{*}{$\begin{array}{l}\text { The socioeconomic } \\
\text { status of the elderly }\end{array}$} & \multicolumn{2}{|c|}{$\begin{array}{l}\text { Income level of the } \\
\text { elderly }\end{array}$} & 3.05 & 2.15 & 3.69 & 3.87 & 3.22 & 2.60 \\
\hline & \multicolumn{2}{|c|}{$\begin{array}{l}\text { The educational level } \\
\text { of the elderly }\end{array}$} & 2.92 & 2.34 & 3.46 & 4.01 & 3.37 & 2.58 \\
\hline \multirow[t]{6}{*}{$\begin{array}{l}\text { The socioeconomic } \\
\text { status of the child }\end{array}$} & $\begin{array}{l}\text { The } \\
\text { educational }\end{array}$ & $\begin{array}{l}\text { The } \\
\text { oldest }\end{array}$ & 3.39 & 2.84 & 3.85 & 4.28 & 3.67 & 2.98 \\
\hline & \multirow[t]{2}{*}{$\begin{array}{l}\text { level of } \\
\text { children }\end{array}$} & $\begin{array}{l}\text { The } \\
\text { second }\end{array}$ & 3.32 & 2.88 & 3.69 & - & 3.74 & 3.03 \\
\hline & & $\begin{array}{l}\text { The } \\
\text { third }\end{array}$ & 3.10 & 2.57 & 3.54 & - & - & 3.10 \\
\hline & $\begin{array}{l}\text { The } \\
\text { economic }\end{array}$ & $\begin{array}{l}\text { The } \\
\text { oldest }\end{array}$ & 3.12 & 2.98 & 3.24 & 3.18 & 3.16 & 3.09 \\
\hline & \multirow[t]{2}{*}{$\begin{array}{l}\text { condition } \\
\text { of children }\end{array}$} & $\begin{array}{l}\text { The } \\
\text { second }\end{array}$ & 3.17 & 3.11 & 3.22 & - & 3.18 & 3.10 \\
\hline & & $\begin{array}{l}\text { The } \\
\text { third }\end{array}$ & 3.08 & 2.98 & 3.16 & - & - & 3.08 \\
\hline \multirow[t]{3}{*}{ Control variable } & \multicolumn{2}{|l|}{ Age } & 69.76 & 69.38 & 70.01 & 65.21 & 66.94 & 72.16 \\
\hline & \multicolumn{2}{|c|}{$\begin{array}{l}\text { Number of children } \\
\text { living }\end{array}$} & 1.50 & 1.50 & 1.50 & 1.45 & 1.48 & 1.53 \\
\hline & \multicolumn{2}{|l|}{ Gender } & 3.26 & 3.37 & 3.15 & 3.02 & 3.38 & 3.25 \\
\hline
\end{tabular}

phenomenal character: the health status gap between urban and rural elderly decreases with the increase of the number of children.To more clearly compare urban and rural health inequalities among elderly with different numbers of children, we used the cluster mean comparison method in structural equation modeling. In this method, instead of giving specific values of the mean values of latent variables for each group, we set the mean value of a group to 0 , the measure standards, and gave the difference between the mean values of latent variables of different groups and measure standards. In this study, we set the mean value of health level of elderly in the urban group as 0 , and the value listed in the rural group was the difference with the urban group. From one child to multiple children, the difference in health level of rural elderly compared to urban elderly was $-0.45,-0.31$ and -0.19 in order (Fig. 2). This implies thatwith the increase of the number of children, the health gap between urban and rural elderly gradually narrowed; in other words, the health gap between urban and rural elderly in China showed convergence with the increase in the number of children. We further analyzed the means of the child quality and elderly socioeconomic status variables in the different groups models, as shown in Table 2, Fig. 3. 
Table 2

the urban-rural gap in mean values of different number groups of children model variables

\begin{tabular}{|c|c|c|c|c|c|c|}
\hline \multirow[t]{3}{*}{ Groups } & & \multicolumn{5}{|c|}{ Estimated value of the mean } \\
\hline & & $\begin{array}{l}\text { Income level of } \\
\text { the elderly }\end{array}$ & $\begin{array}{l}\text { The educational level } \\
\text { of the elderly }\end{array}$ & $\begin{array}{l}\text { The } \\
\text { educational }\end{array}$ & $\begin{array}{l}\text { The } \\
\text { economic }\end{array}$ & $\begin{array}{l}\text { The health status } \\
\text { of the elderly }\end{array}$ \\
\hline & & & & $\begin{array}{l}\text { level of } \\
\text { children }\end{array}$ & $\begin{array}{l}\text { condition } \\
\text { of children }\end{array}$ & \\
\hline \multirow[t]{2}{*}{ One child } & Urban & 0 & 0 & 0 & 0 & 0 \\
\hline & Rural & -1.88 & -1.72 & -1.36 & -0.51 & -0.45 \\
\hline \multirow[t]{2}{*}{ Two children } & Urban & 0 & 0 & 0 & 0 & 0 \\
\hline & Rural & -1.47 & -1.06 & -0.94 & -0.28 & -0.31 \\
\hline \multirow{2}{*}{$\begin{array}{l}\text { Three or more } \\
\text { children }\end{array}$} & Urban & 0 & 0 & 0 & 0 & 0 \\
\hline & Rural & -0.99 & -0.95 & -0.71 & -0.23 & -0.19 \\
\hline
\end{tabular}

In terms of the change rule of urban-rural gap with the number of children, the urban-rural gap in the health status of the elderly, the socioeconomic status of the elderly, and the quality of children all showed a gradual decrease with the increase in the number of children. However, although the direction of change in the urban-rural gap was consistent for the means of all variables, there are large differences in the degree of change. As the number of children increases, the degree of change in the health gap of elderly was highly consistent with the degree of change in the urban-rural gap in the economic conditions of children, while it was very different from the degree of change in the urban-rural gap in the socioeconomic status of elderly.

Internal mechanism:Significant impact of children's economic conditions. The number of children were substituted into the model for group comparison. The fitting result are shown in Table 3, and standardization coefficients (path) are shown in Fig. 4. Comparing the total effect of child quality on the health status of the elderly, it can be seen that the economic condition of children have significant positive effects on the health status of all urban and rural elderly, and it was also the factor with the largest effect value. From one child to multiple children, the total effects of the health status of urban elderly affected by children's economic conditions were $0.138,0.280$, and 0.201 respectively, and the total effects of the health status of rural elderly affected by children's economic conditions were $0.330,0.320$, and 0.270 respectively. 
Table 3

Urban-rural comparison of model fitting results for different number of child groups

\begin{tabular}{|c|c|c|c|c|c|c|c|c|c|}
\hline \multicolumn{2}{|c|}{ Independent variable } & \multirow[t]{3}{*}{ Group } & \multicolumn{4}{|c|}{ Partial intermediary variable } & \multicolumn{3}{|c|}{ Dependent Variable } \\
\hline & & & \multirow{2}{*}{$\begin{array}{l}\text { The } \\
\text { educational } \\
\text { level of } \\
\text { children }\end{array}$} & \multicolumn{3}{|c|}{$\begin{array}{l}\text { The economic condition of } \\
\text { children }\end{array}$} & \multicolumn{3}{|c|}{ The health status of the elderly } \\
\hline & & & & $\begin{array}{l}\text { The } \\
\text { total } \\
\text { effects }\end{array}$ & $\begin{array}{l}\text { The } \\
\text { direct } \\
\text { effect }\end{array}$ & $\begin{array}{l}\text { The } \\
\text { indirect } \\
\text { effects }\end{array}$ & $\begin{array}{l}\text { The } \\
\text { total } \\
\text { effects }\end{array}$ & $\begin{array}{l}\text { The } \\
\text { direct } \\
\text { effect }\end{array}$ & $\begin{array}{l}\text { The } \\
\text { indirect } \\
\text { effects }\end{array}$ \\
\hline \multirow{8}{*}{$\begin{array}{l}\text { One } \\
\text { child }\end{array}$} & \multirow{2}{*}{$\begin{array}{l}\text { Income } \\
\text { level of the } \\
\text { elderly }\end{array}$} & Urban & 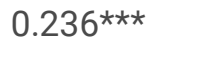 & $0.208^{* * *}$ & $0.141^{\star \star \star}$ & $0.067 * \star \star$ & $0.101^{\star \star}$ & 0.068 & $0.032^{\star * *}$ \\
\hline & & Rural & $0.324^{\star \star \star}$ & $0.256^{\star * *}$ & $0.187^{\star \star}$ & $0.069 * * *$ & $0.259 * \star$ & $0.210 * \star$ & $0.049 * *$ \\
\hline & \multirow{2}{*}{$\begin{array}{l}\text { The } \\
\text { educational } \\
\text { level of the } \\
\text { elderly }\end{array}$} & Urban & $0.309 * * \star$ & $0.137 * \star \star$ & 0.050 & $0.087 * \star \star$ & 0.018 & -0.005 & 0.024 \\
\hline & & Rural & $0.172^{\star \star}$ & 0.144 & 0.108 & 0.037 & 0.007 & -0.022 & 0.029 \\
\hline & $\begin{array}{l}\text { The } \\
\text { educational }\end{array}$ & Urban & - & $0.281 * * *$ & $0.281 * \star \star$ & - & 0.054 & 0.015 & 0.039 \\
\hline & $\begin{array}{l}\text { level of } \\
\text { children }\end{array}$ & Rural & - & $0.213^{\star \star \star}$ & $0.213^{\star \star \star}$ & - & -0.039 & -0.109 & 0.070 \\
\hline & $\begin{array}{l}\text { The } \\
\text { economic }\end{array}$ & Urban & - & - & - & - & $0.138 * \star \star$ & $0.138 * \star \star$ & - \\
\hline & $\begin{array}{l}\text { condition } \\
\text { of children }\end{array}$ & Rural & - & - & - & - & $0.330 * \star *$ & $0.330 * \star \star$ & - \\
\hline \multirow{8}{*}{$\begin{array}{l}\text { Two } \\
\text { children }\end{array}$} & \multirow{2}{*}{$\begin{array}{l}\text { Income } \\
\text { level of the } \\
\text { elderly }\end{array}$} & Urban & $0.281^{\star \star \star}$ & $0.241^{* * *}$ & $0.145^{\star \star \star}$ & $0.096 * \star \star$ & $0.104 * \star \star$ & 0.016 & $0.088^{* \star *}$ \\
\hline & & Rural & $0.258 * \star \star$ & $0.264^{\star \star *}$ & $0.198 * \star \star$ & $0.066^{\star \star \star}$ & $0.291^{\star \star \star}$ & $0.197^{\star \star \star}$ & 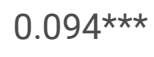 \\
\hline & \multirow{2}{*}{$\begin{array}{l}\text { The } \\
\text { educational } \\
\text { level of the } \\
\text { elderly }\end{array}$} & Urban & $0.391^{\star * \star}$ & $0.132^{* * *}$ & -0.002 & $0.134^{\star \star \star}$ & 0.048 & -0.008 & 0.066 \\
\hline & & Rural & $0.317 * * \star$ & 0.073 & -0.007 & 0.081 & 0.028 & -0.008 & 0.036 \\
\hline & $\begin{array}{l}\text { The } \\
\text { educational }\end{array}$ & Urban & - & $0.343^{* \star *}$ & $0.343^{\star \star \star}$ & - & 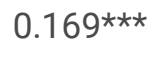 & 0.073 & $0.096 * \star \star *$ \\
\hline & $\begin{array}{l}\text { level of } \\
\text { children }\end{array}$ & Rural & - & $0.255^{\star \star \star}$ & $0.255^{\star \star \star}$ & - & 0.120 ** & 0.039 & $0.082^{\star \star \star}$ \\
\hline & $\begin{array}{l}\text { The } \\
\text { economic }\end{array}$ & Urban & - & - & - & - & 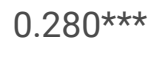 & $0.280^{\star \star \star *}$ & - \\
\hline & $\begin{array}{l}\text { condition } \\
\text { of children }\end{array}$ & Rural & - & - & - & - & 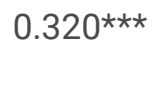 & $0.320 * \star \star$ & - \\
\hline \multirow{6}{*}{$\begin{array}{l}\text { Three } \\
\text { or more } \\
\text { children }\end{array}$} & \multirow{2}{*}{$\begin{array}{l}\text { Income } \\
\text { level of the } \\
\text { elderly }\end{array}$} & Urban & $0.278 * \star \star *$ & $0.223^{* * *}$ & $0.146 * \star \star *$ & $0.077 * \star \star *$ & $0.108 * \star \star *$ & 0.057 & $0.051 * * *$ \\
\hline & & Rural & $0.244^{\star \star \star}$ & $0.194 * * *$ & 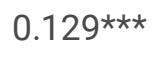 & $0.065^{\star \star \star}$ & $0.218 * \star \star$ & $0.164 * \star \star$ & $0.054 \star \star \star *$ \\
\hline & \multirow{2}{*}{$\begin{array}{l}\text { The } \\
\text { educational } \\
\text { level of the } \\
\text { elderly }\end{array}$} & Urban & $0.401^{\star \star \star}$ & $0.103^{* * *}$ & -0.007 & $0.121 * \star \star$ & $0.107 * \star \star$ & $0.076 * \star \star *$ & 0.020 \\
\hline & & Rural & 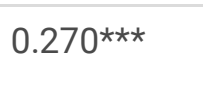 & 0.040 & -0.032 & 0.072 & $0.083^{\star \star \star}$ & $0.071^{\star \star \star}$ & 0.012 \\
\hline & $\begin{array}{l}\text { The } \\
\text { educational }\end{array}$ & Urban & - & $0.275^{\star \star \star}$ & $0.275^{\star \star \star}$ & - & $0.080 * \star *$ & 0.025 & $0.055^{\star \star \star}$ \\
\hline & $\begin{array}{l}\text { level of } \\
\text { children }\end{array}$ & Rural & - & $0.266^{* * *}$ & $0.266^{\star \star \star}$ & - & $0.077 * \star$ & 0.006 & $0.072^{\star \star *}$ \\
\hline
\end{tabular}




\begin{tabular}{|c|c|c|c|c|c|c|c|c|}
\hline $\begin{array}{l}\text { The } \\
\text { economic }\end{array}$ & Urban & - & - & - & - & $0.201 * \star \star *$ & $0.201^{* * *}$ & - \\
\hline $\begin{array}{l}\text { condition } \\
\text { of children }\end{array}$ & Rural & - & - & - & - & $0.270 * \star \star$ & $0.270 * \star \star$ & - \\
\hline
\end{tabular}

The educational level of children did not have a significant positive effect on the health status of all urban and rural elderly, but only significantly affected the health status of elderly who had two children and multiple children (one child was not significant). From 2 children to multiple children. The total effect values of the health status of the urban elderly affected by the education level of their children were 0.169 and 0.080 , respectively, while the total effect values for the rural elderly are 0.120 and 0.077 respectively.

The effect value of elderly' own socioeconomic status positively influencing their health status was smaller than that of children's quality. The effect values of income level on health status were $0.101,0.104$, and 0.108 for urban elderly, and $0.259,0.291$, and 0.218 for rural elderly, in the order of one to multiple children. The effect of education level on health was significant only in the multiple children group, but not in the 1-child and 2-child groups.

The indirect effects of income level on health level were significant for all urban and rural elderly, indicating that child quality was the mediator variable in the path. The direct effect of living environment on the quality of life of the elderly was not significant, but that of indirect effect was significant. That indicated that child quality were the complete mediator variables in this path. Both direct and indirect effects of rural elderly income level on the health level were significant, indicating that child quality was part of the mediator variables in this path.

\section{Discussion}

In this study, we analyzed the urban and rural health inequality of the elderly in China based on the 2014 data of the Chinese Longitudinal Social Survey (CLASS), revealed the characteristics of urban and rural health inequality of the elderly with the same number of children, and explored the internal mechanism of urban and rural health inequality of the elderly.

We confirmed the existence of health inequality between urban and rural elderly (Du Benfeng, Wang Xuan, 2013; Hangqing and Chen Gong, 2017) $[8,40]$. In addition, we found an interesting phenomenon, that was, the urban-rural health gap of the elderly converges with the increase of the number of children, which showed that with the increase of the number of children, the urban-rural health inequality of the elderly gradually decreases. In other words, the health gap between urban and rural elderly in China showed convergence with the increase in the number of children.

We confirmed that child quality has a significant effect on the health level of elderly (Zimmer 2007; Yahirun et al. 2017; Brooke et al. 2017)[17, 20,21], especially that the economic conditions of children have a stable and significant effect on the health of elderly with different number of children. At the same time, we found that the pathway of the effect of child quality on the health status of elderly differed significantly between different cohorts of elderly with different numbers of children, and did not differ significantly between urban and rural elderly with the same number of children. This finding has two implications: first, despite the obvious urban-rural dichotomy in China and the significant differences between urban and rural areas in terms of economic development and socio-cultural aspects, there is no significant difference in family structure and intergenerational relationships determined by the number of children and the impact of children on the health of elderly. Second, it confirms the need to explore urban-rural health inequalities among elderly by number of children subgroups.

We confirmed that the impact of child quality on elderly health status was greater than the impact of elderly' own socioeconomic status on their health, a finding that not only validates the findings of existing scholars (Torssander, 2014; Yahirun et al., 2016)[22,41], but also implied that for Chinese elderly, the "individual" factors affecting health are weaker and the "child" factors are stronger, and family socioeconomic status, as determined by child quality, has a greater impact on elderly' health. We also confirmed that the effect of elderly' income level on their health was mediated by children's quality, 
implying that the importance of children's quality on elderly' health is not only reflected in its own high effect on elderly' health, but also in its role as a mediator in the pathway of elderly' income level on their health.

The degree of urban-rural health inequality of the elderly changes in the same direction as the economic conditions of their children. Therefore, children's economic conditions are not only an important influencing factor on elderly health, but also one of the important reasons for the convergence of the urban-rural gap in elderly' health with the increase in the number of children. However, the urban-rural gap between the quality of children, especially the economic conditions of children, and the health status of the elderly is relatively small, and the degree of change in the urban-rural gap in the health status of the elderly is almost synchronized with the economic conditions of children, which means that the degree of urban-rural economic inequality in China has been reduced, and it is because of the reduction of the urban-rural gap in the economic conditions of children that the urban-rural gap in the health status of the elderly has been reduced. This means that urbanrural economic inequalities in China have narrowed, and it is the narrowing of the urban-rural gap in the economic conditions of the offspring that has led to an overall reduction in urban-rural health inequalities among the elderly.

It needs to be addressed that limitations still exist in this research. First of all, this study is based on cross-sectional data, so there is no discussion on the causal relationship between children's quality and the health of the elderly, which needs further verification based on follow-up data. Secondly, this study is based on CLASS data, and the score of children's economic conditions is based on the subjective judgment of the elderly. Although there are many difficulties in the objective data collection of children's income, in the follow-up study, the combination of subjective and objective data of children's economic conditions will be more conducive to the in-depth excavation and comprehensive revelation of the relationship between children's quality and the health of the elderly and health inequality.

\section{Conclusion}

By grouping and comparing the number of children, urban and rural areas and other aspects, we explored the internal logic of the impact of children on the health of the elderly, and revealed the important role of children's quality in the health inequality of urban and rural elderly in China.

With the increase of the number of children, the degree of health inequality between urban and rural elderly decreases with the increase of the number of children. Children's quality, especially their economic status, played an important role in the health of the elderly, and was even significantly greater than the impact of their own socio-economic status. With the change of the number of children, the urban-rural health inequality of the elderly and the urban-rural gap of children's economic conditions changed in the same direction. The economic conditions of children were not only an important factor affecting the health of the elderly, but also one of the important reasons for the convergence of the urban-rural health gap of the elderly with the increase of the number of children.

The conclusions of this study not only enrich the content of elderly health influencing factors, but also help to improve the living standards of rural residents and improve the health status of rural elderly people, and help to alleviate the urban and rural health inequality of the elderly in China, and ultimately effectively promote social equity in China.We call for a special focus on improving the education and income levels of young people in rural China, which will not only help to improve the living standards of rural residents and the health status of rural elderly, but also help to alleviate urban-rural health inequalities among the elderly in China, and ultimately effectively promote social equity in China.

\section{Abbreviations}

\section{SEM}

structural equation Modeling

CFI

goodness-of-fit index 
IFI

incremental fit index

$\mathrm{X} 2 / \mathrm{DF}$

Chi-Square/Degree of freedom

RMSEA

Root Mean Square Error of Approximation.

\section{Declarations}

\section{Ethics approval and consent to participate}

The data used in this manuscript were from a large national social survey(CLASS) and the survey was approved by Academic Ethics Committee of Renmin University of China, but the ethics number has not been publicly released. All participants provided written informed consent. All methods emploved in the study were performed in accordance with the relevant international guidelines and regulations.

\section{Consent for publication}

Not applicable

\section{Availability of data and materials}

The data that support the findings of this study are available on the website of the China Longitudinal Aging Social Survey (CLASS ) at http://class.ruc.edu.cn/. To access and use this survey data for research purposes, please contact the China Survey Data Center of Renmin University of China (email: class@nsrcruc.org).

\section{Competing interests}

The authors declare that they have no competing interests.

\section{Funding}

General project of the National Social Science Fund, "Research on the mechanism and countermeasures of rural living environment affecting the health of the elderly from the perspective of active aging" (21BRK020).

\section{Authors' Contributions:}

Conceptualization: Z.Z. and H.C.; Data curation: Z.Z..; Formal analysis, Z.Z.; Methodology: Z.Z. and H.C.; Validation: Y.C. and H.C.; Investigation: H.C. and Y.C.; Software: Y.C.; Resources: Z.Z.; Writing-original draft preparation: L.Y.; writing-review and editing: H.C.; Visualization: W.L. and H.C.; Supervision: N.S.; Project administration: H.C.; Funding acquisition: Z.Z.

\section{Acknowledgments}

Not applicable.

\section{Authors' information}

${ }^{1}$ College of Communication and Art Design, University of Shanghai for Science and Technology, No.516, Jungong Road, Shanghai 200093, China; zhenhuazheng@usst.edu.cn

2 Institute of Local Governance, Yangtze Normal University, Chongging,China 
${ }^{3}$ College of Architecture \& Environment, Sichuan University, No.24 First South Section First Ring Road, Chengdu 610065, China

*Correspondence: ch_jhxy@sina.com; Tel. +86-1388-053-9664

\section{References}

1. Chen Jieming, Chen Qi. (2016). Intergenerational socioeconomic status and co-living arrangements: An analysis of the living style of the elderly in China. Sociological Research (1), 25.(in chineses)

2. Braveman, P. (2006). Health disparities and health equity: concepts and measurement. Annu. Rev. Public Health, 27, 167-194.

3. Claussen B. 2015,“Socioeconomic Status and Health."International Encyclopedia of the Social \& Behavioral Sciences 18.

4. Black, D. (1999). A black look at the independent inquiry into inequalities in Health. Journal of the Royal College of Physicians of London, 33(2), 148-149.

5. Marmot, M. (2005). Social determinants of health inequalities. The lancet, 365(9464), 1099-1104.

6. Scambler G. 2012,“Health inequalities."Sociology of Health \& Illness 34.

7. Zhou, Z., Fang, Y., Zhou, Z., Li, D., Wang, D., Li, Y.,. \& Chen, G. (2017). Assessing income-related health inequality and horizontal inequity in China. Social Indicators Research, 132(1), 241-256.

8. Du, B. F., \& Wang, X. (2013). Health inequality among the Chinese elderly: changes, regional disparities and determinants. Popul Res, 37(5), 81-90.(in chineses)

9. Wen Yong, Zong Zhanhong, Shu Xingyu, Zhou Jianfang, Sun Xiaoming, \& Ru Xiaomei. (2014). Health status, demand and provision of health services in middle-aged and elderly people. Population Research, 38(5), 15.(in chineses)

10. Qi, L. S. (2006). Income, income inequality and health: the impacts of rural-urban gap and occupational status. Econ Res J, 11, 16-26.(in chineses).

11. Du Benfeng, \& Wang Xuan. (2013). Evolution, regional differences and influencing factors of health inequality among the elderly. Population Research, 37(5), 10.(in chineses).

12. Ruan Hangqing, \& Chen Gong. (2017). Income-related health inequalities and their decomposition among the elderly in China: A case study of Beijing. Population and Economy (5), 11.(in chineses).

13. Li Ting, \& Zhang Yanlong. (2014). Growth curves and urban-rural differences of elderly health indicators under the effect of birth cohort. Population Research, 38(2), 18.(in chineses).

14. Liu Changping, \& Wang Lianjie. (2017). A study on the influence of socioeconomic status on the health status of the elderly. Chinese Population Science (5), 11.(in chineses).

15. Shi, Z. (2016). Does the number of children matter to the happiness of their parents? The Journal of Chinese Sociology, $3(1), 1-24$.(in chineses).

16. Zhang Chuanchuan, \& Chen Binkai. (2014). Can "social pension" replace "family pension"?--Evidence from China's new rural social pension insurance. Economic Research, 49(11), 14.(in chineses).

17. Zimmer, Z., Martin, L. G., Ofstedal, M. B., \& Chuang, Y. L. (2007). Education of adult children and mortality of their elderly parents in Taiwan. Demography, 44(2), 289-305.

18. Raymo, J. M., Liang, J., Hidehiro, S., Erika, K., \& Yoko, S.. (2004). Work at older ages in japan: variation by gender and employment status. Journals of Gerontology(3), S154-63.(in chineses).

19. Zimmer, Z., Hermalin, A. I., \& Lin, H. S. (2002). Whose education counts? The added impact of adult-child education on physical functioning of older Taiwanese. The Journals of Gerontology Series B: Psychological Sciences and Social Sciences, 57(1), S23-S32.

Page $12 / 16$ 
20. Yahirun, J. J., Sheehan, C. M., \& Hayward, M. D. (2017). Adult children's education and changes to parents' physical health in Mexico. Social Science \& Medicine, 181, 93-101.

21. Brooke, H. L., Weitoft, G. R., Talbäck, M., Feychting, M., \& Ljung, R. (2017). Adult children's socioeconomic resources and mothers' survival after a breast cancer diagnosis: a Swedish population-based cohort study. BMJ open, 7(3), e014968.

22. Torssander, J. (2014). Adult children's socioeconomic positions and their parents' mortality: a comparison of education, occupational class, and income. Social science \& medicine, 122, 148-156.

23. Torssander, J. (2013). From child to parent? The significance of children's education for their parents' longevity. Demography, 50(2), 637-659.

24. Buber, I., \& Engelhardt, H. (2008). Children's impact on the mental health of their older mothers and fathers: findings from the Survey of Health, Ageing and Retirement in Europe. European Journal of Ageing, 5(1), 31-45.

25. Angeles, L.. (2010). Erratum to: children and life satisfaction. Journal of Happiness Studies, 11(4), 539-539.

26. Watson, J. A., \& Kivett, V. R. (1976). Influences on the life satisfaction of older fathers. The Family Coordinator, 25(4), 482-488.

27. Ye Yongli, Zhong Ying, Wu Yanhe, Huang Jingye, Xiao Lingjun, \& Zhao Liang et al. (2007). Correlation between quality of life and living conditions of the elderly in rural areas. Chinese Journal of Gerontology, 27(1), 3.(in chineses).

28. Xia Chuanling, \& Ma Fengli. (1995). The influence of the number of children on family pension function. Population Research (1), 7.(in chineses).

29. Elo, I. T. (2009). Social class differentials in health and mortality: Patterns and explanations in comparative perspective. Annual review of sociology, 35, 553-572.

30. Link, B. G., Phelan, J. C., Miech, R., \& Westin, E. L. (2008). The resources that matter: fundamental social causes of health disparities and the challenge of intelligence. Journal of health and social behavior, 49(1), 72-91.

31. Crockerham W C. 2010, Medical sociology. Upper Saddle River: Prentice Hall.

32. Yip, W., Subramanian, S. V., Mitchell, A. D., Lee, D. T., Wang, J., \& Kawachi, I. (2007). Does social capital enhance health and well-being? Evidence from rural China. Social science \& medicine, 64(1), 35-49.

33. Read, S., Grundy, E., \& Foverskov, E. (2016). Socio-economic position and subjective health and well-being among older people in Europe: a systematic narrative review. Aging \& mental health, 20(5), 529-542.

34. Maddox, G. L., \& Douglass, E. B. (1973). Self-assessment of health: A longitudinal study of elderly subjects. Journal of health and social behavior, 87-93.

35. Ocampo, J. M. (2010). Self-rated health: Importance of use in elderly adults. Colombia Médica, 41(3), 275-289.

36. Shi Zhilei. (2015). More children may not be more blessed: reproductive decision-making, family pension and the quality of life of the rural elderly. Sociological Research (5), 27.

37. Fang Fuqian, \& Lv Wenhui. (2007). Viewing my country's Equity Issues from the Evolution of Social Welfare Function. Tianjin Social Sciences (3), 6.

38. Chen, J., \& Chen, Q. (2016). Parent-child socioeconomic statuses and co-residence: an analysis of living arrangements in China. Sociological Studies, 1, 73-97.(in chineses).

39. Kuklys, W. (2005). Amartya Sen's capability approach: Theoretical insights and empirical applications.

40. Hangqing, R. U. A. N., \& Gong, C. H. E. N. (2017). Decomposition of Income-Related Inequalities in Health among Chinese Elderly: Based on the Data from Beijing. Population \& Economics, 05.(in chineses).

\section{Figures}




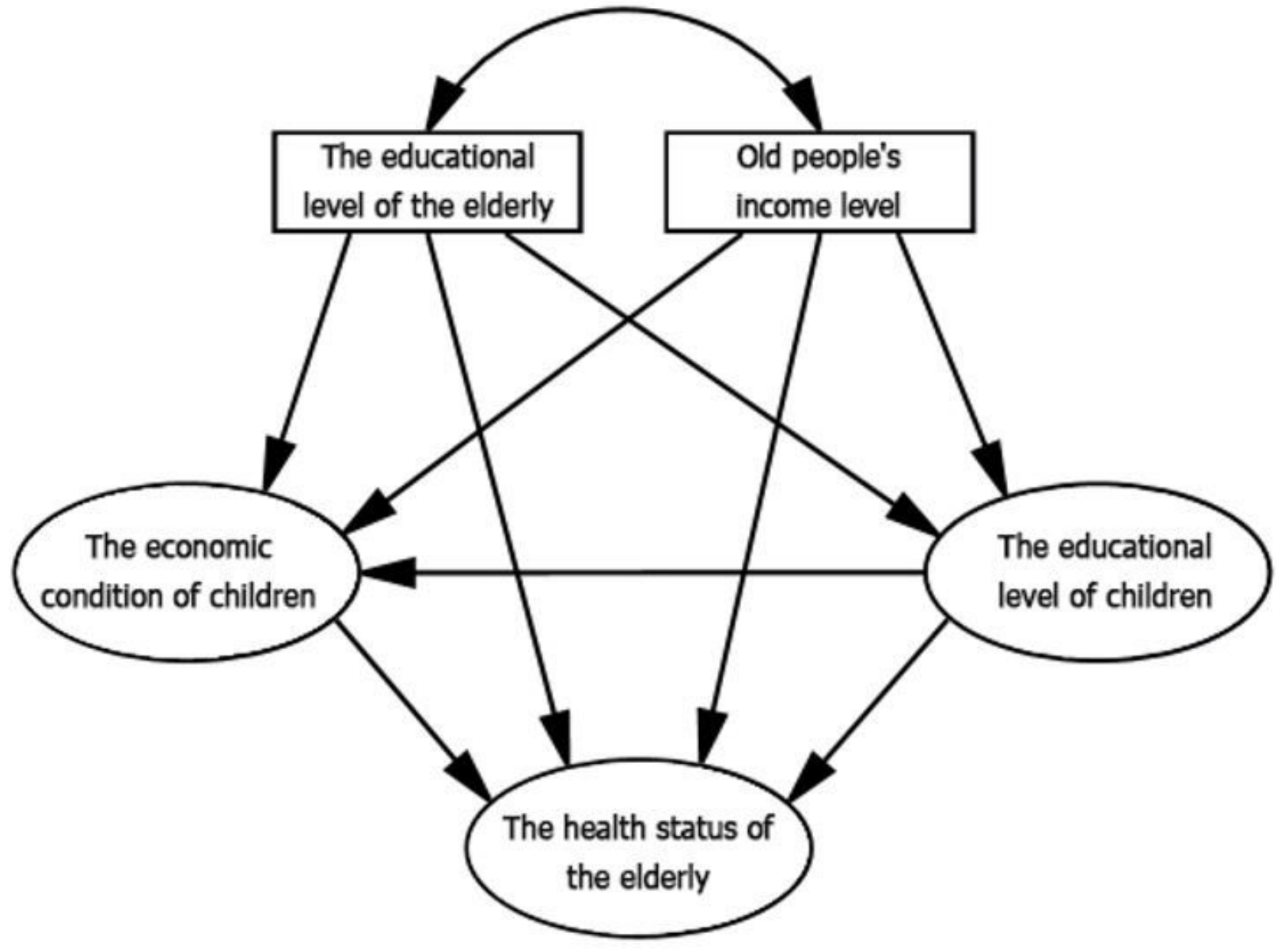

Figure 1

Model assumptions of intergenerational socioeconomic status and health level in old age 


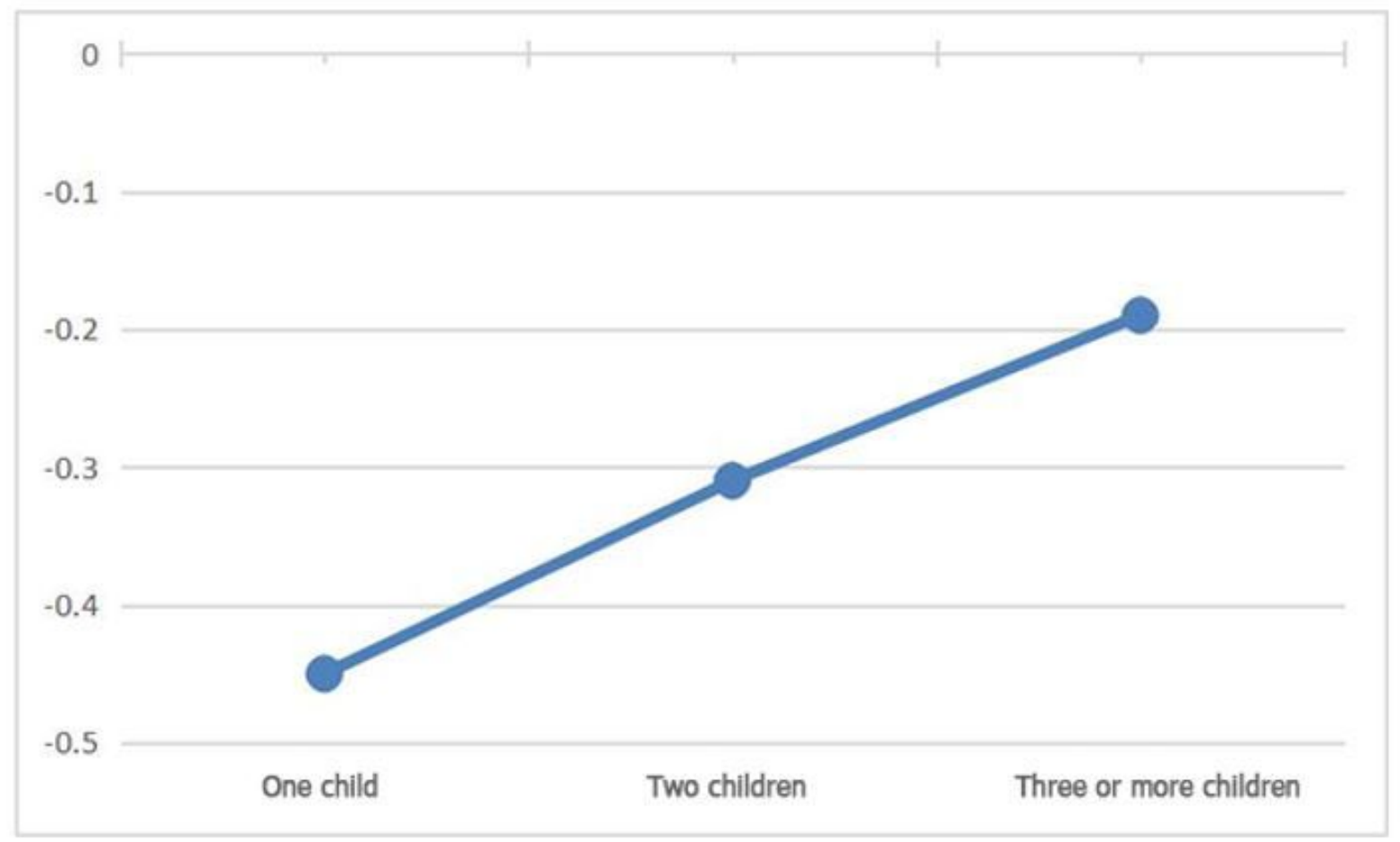

\section{Figure 2}

The urban-rural health gap among the elderly with different number of children

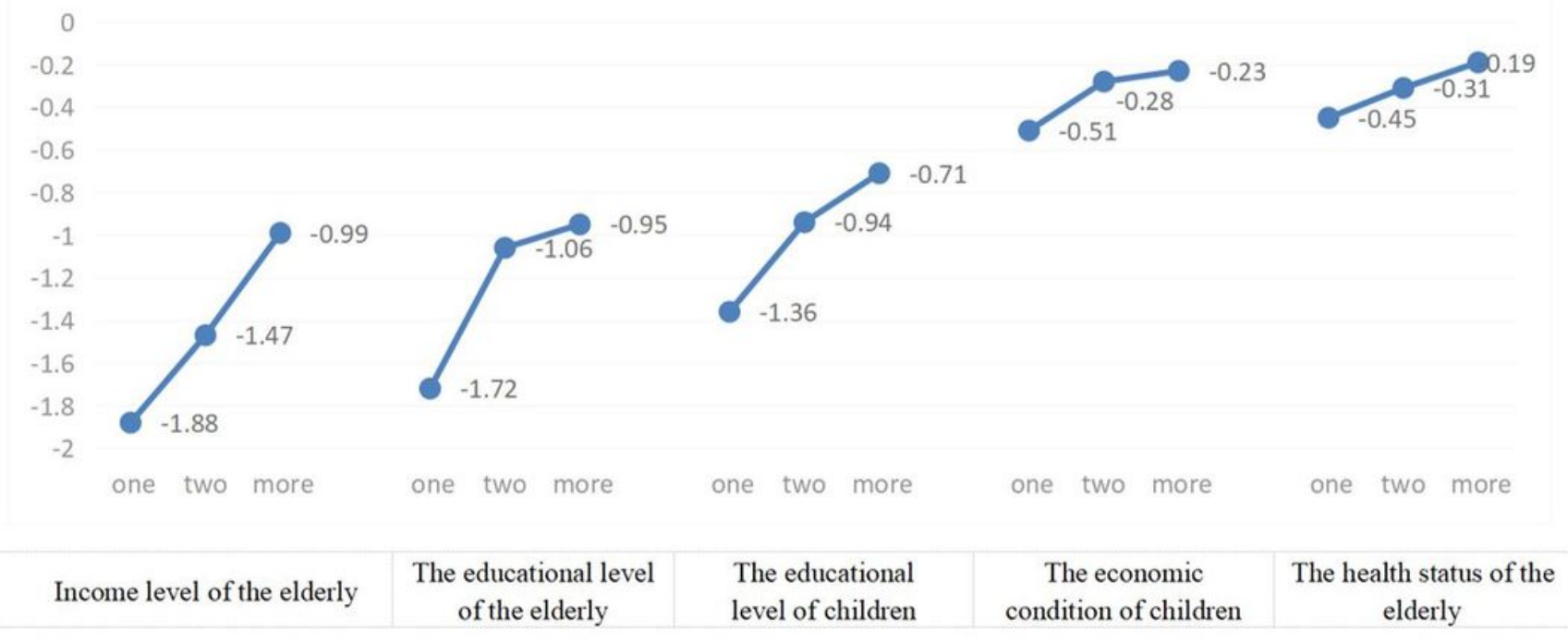

\section{Figure 3}

Group comparison of variable mean urban-rural gap 
The economic condition of children

The educational level of children

Control variable

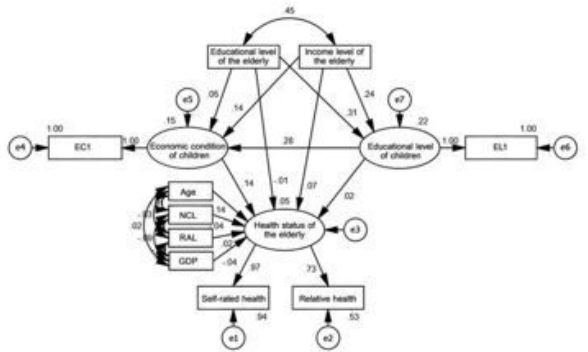

a: Urban area; One child

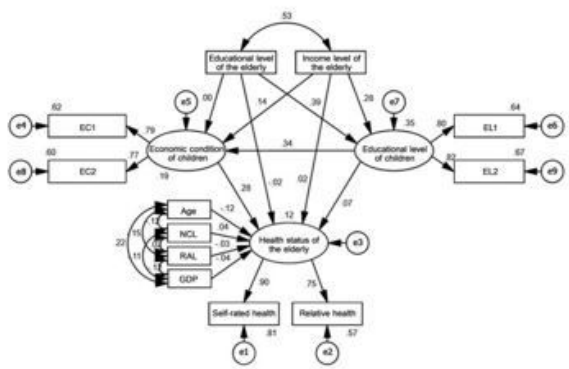

c: Urban area; Two children

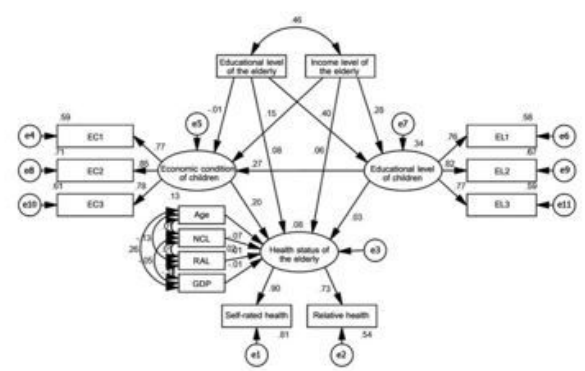

e: Urban area; Three or more children
EC1:The economic condition of the oldest

EC2:The economic condition of the second

EC3:The economic condition of the third

EL1:The educational level of the oldest

EL2:The educational level of the second

EL3:The educational level of the third

Age

NCL:Number of children living

RAL:Residential area location

GDP:GDP per capita

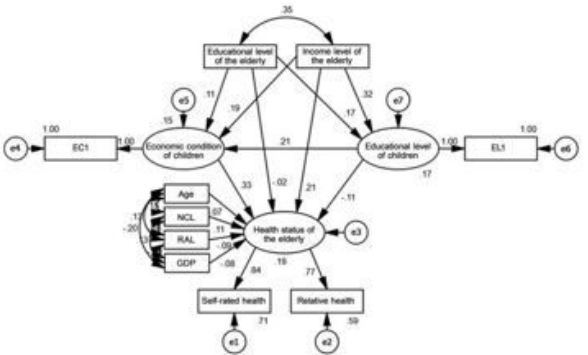

b: Rural area; One child

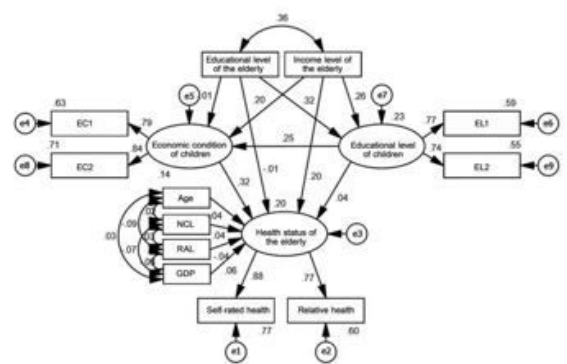

d: Rural area; Two children

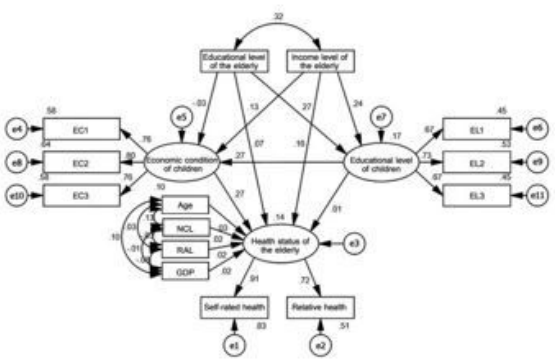

f: Rural area; Three or more children

\section{Figure 4}

Comparison of standardized pathways 